Scon after the operation the child became tranquil, and in a few hours was permitted to suck the mother, which she afterwards continued to do as usual. Before, however, allowing her to suck, care was taken to tranquilize the mother's mind, by having her absent from the house during the operation, and concealing from her the extent of the wound when she again saw her infant. I am not aware that surgeons are generally impressed with the importance of attention to this circumstance when performing operations on children. If the mind of a nurse is agitated, it is well known that such excitement has more or less influence on her milk, the effects of which milk is more or less hurtful to the child. Some writers on the diseases of children have stated cases to illustrate this fact; and I have met with some striking examples of it, which haveled me to suspect that the supposed dangers of operating on infants have originated, not from the irritation of the operation itself, but from the mind of the nurse being agitated on such an occasion, by changing the quality of the milk, disturbed the health of the child. I once removed a hard, irregular-shaped tumour from behind the augle of the jaw of a child which was suckled by its mother, and no febrile symptoms supervened; the wound suppu. rated kindly and cicatrization was going on, when one night the mother was thrown into a furious passion, immediately after which she suckled the infant. Very soon afterwards the child was seized with con. vulsions, and died in a few hours. Since 1 met with the above case, I lave had opportunities of seeing repeated instances of the pernicious, though not of the fatal, effects on the child of mental agitation in a nurse ; and these have led me to adopt, as a general rule, never to allow an infant to suckle a nurse after an operation, until it has been ascertained that the nurse's mind has not been much agitated; and if it has been so, then to empty the breast by an artificial sucker until she has become tranquilized.

The child passed a very quiet night after the operation, and what seemed a remarkable circumstance was, the very sight degree of excitement which it seemed to create in the general system. The infant continued to suckle as if nothing had been done, and its bowels kept so regular that not even a purrative was afteru ards administered. The wound inflamed but in a very slight degree, and required no dressing. The weather being mild, the child was carried out in the open air on the fourth day after the operation, and daily afterwards. 'The ligature came away spontaneously on the elerenth day, and on the thirteenth day after the operation she hal so perfectly recoveret, that the parents, ansious to return home, travelled to Kettering, a distance of upwards of seventy miles, without the child suffering any inconvenience.

With regard to the changes in the tumour after the operation, I have already noticed the sudden collapse which took place immediately after the carotid artery was tied. On the day following it continued of the same diminished bulk, and of the same dark purple colour, and on feeling it, it seemed either as if the blood which it contained had coagulated, or that it was emptied of its blood ; for instead of being able to squeeze out its contents, the application of pressure made no sensible alteration in its bulk.

No particular circumstances occurred after the child's return home, except a gradual, though not always progressive, diminution in the bulk of the tumour. By degrees more and more of the eyeball became exposed from the lessening of the swelling of the upper eyelid, and then it appeared that the lachrymal caruncle was involved in the disease and was preternaturally swelled and vascular; and last Jauuary (ten months after the operation) Mr. Gibbon wrote - I have to give you the pleasing in. telligence, that the amendment in our little patient has been rapid since my last report, and nothing of the lumour now remains, more than that of the membranous bag, which was originally distended with blood."

Charles-street, St. Tames's-square, May $18 \%$.

\section{ABUSES AT ST. GEORGE'S.}

$A$ Letter to the Independent Governors of $S t$. George's Hospitul, proving a Lass to the Poor, by mismanagement, of (even in Eight Items, ) Ninety Thousand Pounds! By W.W. Sleigh, Esq., one of the Governors of that Charity.

Mr Lords, Ladies, and Gentlemen,-The only apology I shall ofter for thus addressing you is one which, I believe, will be considered satisfactory, viz. that $I$ am vindicating the cause of thousands of our unfortunate fellow-creatures. Regardless, therefore, of the motives that may be attributed to me, I shall, I trust, as a Governor of St. George's Hospital, conscientiously discharge my duty: and by adducing a rew facts only, call forth the exertions of some, whom God has blessed with power to protect the helpless. Previous to my commencing, I would take the liberty of replying to two questions that, in all prebability, will be put to me. First, "Why I have delayed so long without calling the attention of the Governors to these circumstances ?" anc, secondly, " Had I been successtul at the late election, would I erer hare noticed them ?" To the first question, 
I have only to observe, that I detest, if possible, finding fault; and having had reason to believe that I should have been, ere this, so situated as to correct them privately, or that some other person would have taken up the subject, $I$ deferred it to the present time. In answer to the second question, I do solemnly aver, that had I been successful, I should, after private admonition, and private, but determined, opposition, to all corraption, but not till then, have adopted identically this method.*

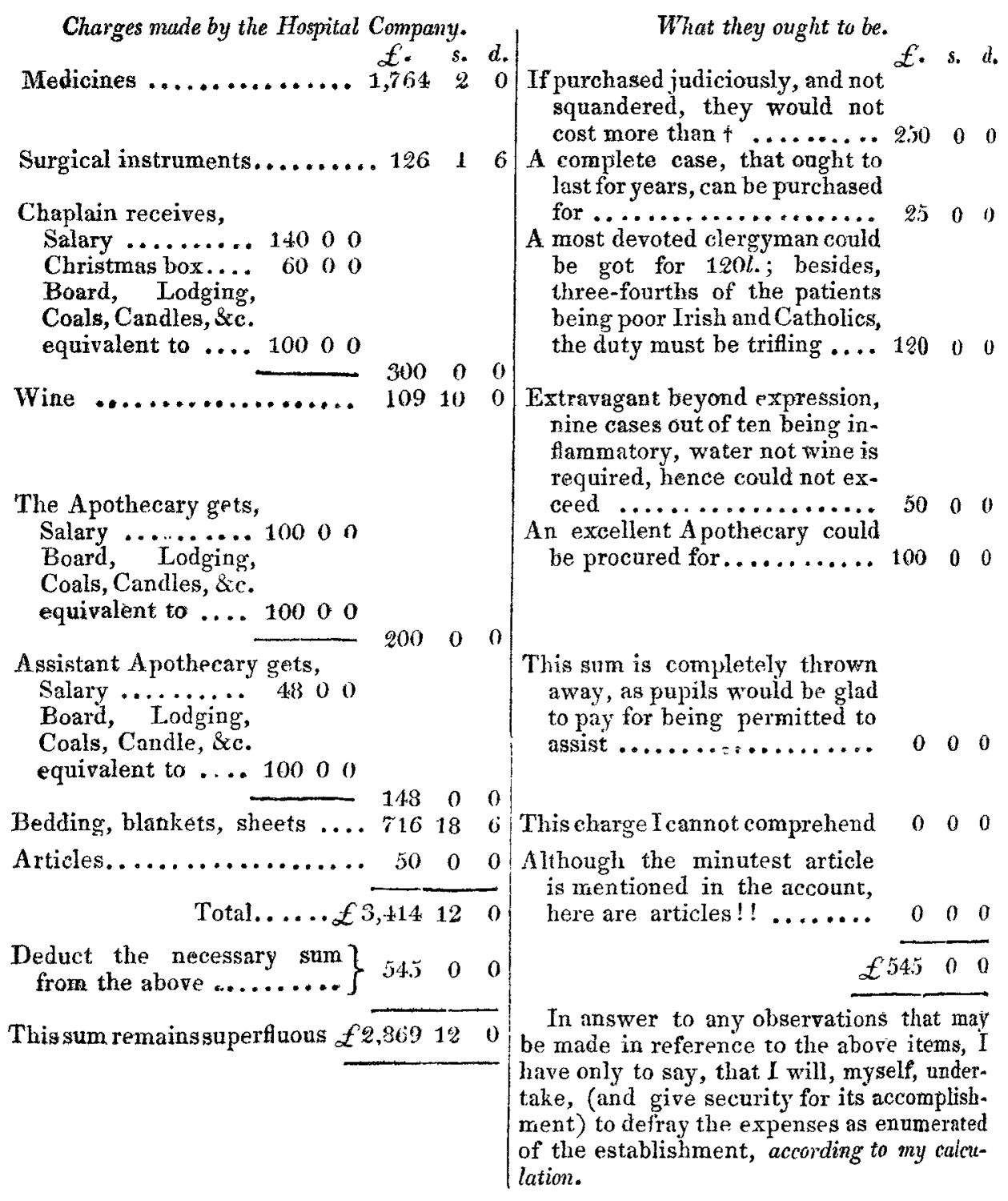

* The extraordinary exertions that were made to keep me out of the Hospital, may justly be attributed to a well founded dread of my opposition, to the ntmost of my power, of all abuse.

i A respectable Surgeon-A pothecary mentioned to me the other day, that he gives medicine to at least 8,000 patients annually, and his druggist's bill does not exceed 1506 . a year. The number of the hospital patients is not one half this, and the expense of medicines elenen times greater. Is this to be attributed to the profligacy with which the medicines are nsed?
After all, what have my motives to do with the question? if they be bad, yet if I adduce facts, if I tell the truth, magnit est itas et pravalehit. On the contrary, if they tempt will bring its own punishment;-I m prepared for the consequences. I shall now proceed to the question, and prove my points, by extracts from the Annual Report of the Hospital, published 1826, and from a private account furnished at my request by the Secretary, dated March 3, 1826. be good, yet if I tell not the trath, the at- 
If $w e$ be permitted to form an opinion of the whole account from these eight items,* it would appear obvious that the property of St. George's Hospital, if not wantonly squandered, could afford relief to ten times the number of patients it now does. And if we reflect that this extravagance, in these eight items only, has existed at least for thirty years, the poor have been plundered of the immense sum of viNETY THOUSA ND POUNDS. What an Hospital this sum would have built! How many persons would it have preserved, in these hard times, from perishing of want! But if there were not thousands in this metropolis who die without the comfort of a home, or the shelter of an asylum, the above abuses might be excusable : if charitable persons give their property to mitigate the sufferings of their fellow creatures, is it not cruel for that property to be appropriated to the enriching of certain selfish individuals?

Some may be inclined to exclaim, how is it possible this evil could have existed?Does not a weekly Board meet? Wonld the Medical Officers sanction it? In reply to these natural exclamations, I beg leave to say, first, the evil does exist; secondly, a weekly Board does meet; thirdly, some of the Medical Officers do sanction it, and others ate afraid to expose it. 1 shall now unravel the mystery. I shall now draw the curtains aside, and show what is doing behind them.

The affairs of the Hospital are nominally managed by a weekly Board, which consists of:-

3. The Chaplain.-Income from the establishment, about $300 \%$.

2. The Medical Officers.-Who on an arerage make by their situations about $2,500 l$.

3. About a dozen junior Surgeons and Physicians. - Who by their courtesy and obedience to their former masters, expect one day or other to get appointed to the Hospital.

4. The Secretary and Collector.

5. About half a dozen elderly Gentlemen.-Their objects are those of pure charity; but are easily led by the more aetive.

* Let it not be imagined that the eight items 1 have mentioned are the only ones in which extravagance is apparent; it is far otherwise, (eg. see the account of coals annually, 387 l.) Nor, that because I hare been silent as it respects other transactions, there is nothing else to be reproved-delicacy, as a surgeon, forbids my noticing them.

The account of the establishment averages yearly $8,441 \% .11 \mathrm{~s} .5 \mathrm{~d}$. If my estimate be accurate, it onght not to exceed $3,000 l$.
6. And lastly, one or two Governors occasionally step in, say- "How do you do? how do you get on?'- -and out they go!*

There would be but little use in appealing to the above Board; what one says, the rest uná voce support, they dare not act otherwise.-In fact, no one dares censure, no one dares to find fault!

What possible interest, some may say, can the Medical Officers have for sanctioning this system? I will tell you.-It is their great interest to possess at their command a number of votes, $f$ for two reasons; first to thwart any attempts that may be made to call in question their practice; and secondly, to bring into the Hospital, as Surgeon, that pupil who most suits their purposes. If they broke through this system, their plans would be rendered void, their adoption of officers to succeed them would very soon fail of success, and their conduct would be scrutinized. Why should they not then support it as long as they possibly can?

Further, in order to render this systemthis Jobbing Company-as impenetrable as possible, they have adopted two measures; the first has no precedent in any similar institution + on the face of the earth. It is, no matter what sum of money you may con. tribute to the Hospital, your name must be posted up for two months in the boardroom, you must be proposed by a Governor, and at the end of the time you must be ballotted for, ere you are acknowledged a governor, or have a voice in the transaction of your own affairs: does not this speak volumes? The second has no precedent in any of the metropolitan hospitals. It is depriving peers of the realm, members of Parliament, and ladies, voting by proxy; that is, allowing them no voice in the trans. action of that institution which actually belongs to them, unless they neglect their own important business, take the trouble to come hundreds of miles to the Hospital, or ladies exhibit themselves at a public election! $\mathrm{It}_{t}$ is scarcely necessary to notice the object for all this; they well know that such personages are for the greater part of the year in the country, and when in town,

* I myself have occasionally attended; but having evinced a disposition to oppose all abuse, I became so obnoxious in the eyes of the Chaplain, that he could not treat me even with the common courtesy of one gentleman to another; and he being always in the chair, I have thought proper to discontinue my attendance.

+ The chaplain, I understand, boasts that he himself, can command a hundred Votes!!

* Of this I am not positive. 
are too busily engaged to attend the Hospi- many synonyma for phrenitis. The unital : and judging correctly, that the most versal cause of these complaints being thus effectual way of supporting their present satisfactorily established and accounted for, system, and guarding against the introduc- in certain degrees of inflammation of that tion of any officious person who might oppose organ, the antiphlogistic regimen necessarily their system, they have virtually deprived followed in most cases, as a practical denine-tenths of the Governors the privilege duction from these premises. Delirium treof saying yes, or no, in the management of mens being included in this generalisation their own institution!! And $I$ have it from as depending on arterial action in the head, the best authority, that it is now in contem- venesection, in order that the treatment plation, amongst the medical officers, to deprive might correspond with the receiced hypo. all the Governors, except themselves, the thesis, has been lately recommended in this privilege of voting at all, fcr the plausible disease by the most respectable authorities. reason, they say, of saving the Governors Opium, wine, spirits,-stimulants, in short, the trouble of being canvassed!! Is it not of all kinds, say these writers, only tend to full time for some active Governor to inves- excite that state of the cerebral functions tigate this subject, to call a General Meeting of the Governors, to appoint from amongst them indiscriminately a Committeeand to have, if not restored to the poor, at all events saved for them for the future, from five to six thousand pounds a-year! Would il not be an act of charity? Would it not be vindicating the cause of the helpless?

To conclnde, my Lords, Ladies, and Gentlemen, you will perceive, in thus attempting to expose corruption, I have undertaken an arduous task. lt will draw upon me the vengeance of all concerned in it-variuus objects will be attributed to me; but while I know that nine-tenths of the Governors are independent-are men of talent, and unshackled in judgment-I may defy the others, and the poisoned darts of calumny that may be hurled at me ; which weapons, if they break not ere they reach me-my shield, integrity, shall make them recoil upon themselves.

I have the honour to be,

My Lords, Ladies, and Gentlemen, Your most devoted and faithful servant,

$$
\text { W. W. SLGIGH. }
$$

23, Chapel-street, Grosvenor-square, May 14 th, $182 \%$.

\section{ROYAL INFIRMAR Y. \\ Case of Delirium Tremens.}

Triere are few, perhaps none, of the various diseases ascribed to a similar condition of the brain, the treatment of which so directly clashes with the theories on this subject, as that of delirium tremens. Difierent modifications of fever, and many other analogous affections, are all, arcording to the fashionable pathology of the day, but so

on which the disease depends; instead, therefore, of employing such agents, you should endeavour to remove the cause of the complaint, by the abstraction of blood. Not. withstanding the consistent simplicity of this view of the matter, nothing can be more opposite to such an opinion than the well. known results of the successful practice hitherto pursued in this affection. For, not only has stimulation produced the most beneficial effects in such cases, butinstances are not wanting to prove that depletion has been fatal. We accordingly find the supporters of the new doctrine somewhat at a loss to reconcile it to the old treatment. Dr. Clutterbuck, who seems not insensible of the difficulty, and who would, no doubt, explain it, " si Pergama," \&c., eludes the task, by cutting at onoe through the "Gordian knot," in a single paragraph of his bighly instructive lectures. The subject, however, deserves a more extonded consideration, and he that could elucidato it would have the merit of removing that which, in the present state of our knowledge, must be looked on as at least a very singular pathological paradox, which the annexed case tends rather to obscure than to iliuminate :-

On the $3 \mathrm{~d}$ of May, in the afternoon, Janet Nichol was admitted into the hospital. She was a young woman of an unusually robust frame, and of plethoric habit. On the preceding night she received a fracture of the radius, and a lacerated wound over the left eye, from falling down a flight of stairs during a fit of intoxication, to which she had previously addicted herself, having, for some time, led an irregular life. She was still under the influence of spirits; complained of pain in the chest and arm, which was placed in a semiflexed position; cold lotion applied, and aperient medicine administered. She remained sensible until the second night after her admission, when she became aflected with violent tremors and insom. nolency. She continued in this state, muttering incoherently, to the following night, 